\title{
PENGARUH REBRANDING DAN PERSEPSI KUALITAS TERHADAP LOYALITAS KONSUMEN DENGAN CITRA MEREK SEBAGAI VARIABEL MEDIASI \\ ( STUDI PADA PEMIRSA TVRI KOTA PADANG )
}

\author{
Ridho Ilviendri' ${ }^{1)}$, Dessy Kurnia Sari ${ }^{1)}$ \\ ${ }^{1)}$ Program Magister Manajemen, Fakultas Ekonomi, Universitas Andalas \\ ridhoilviendri94@gmail.com \\ ${ }^{2)}$ Program Magister Manajemen, Fakultas Ekonomi, Universitas Andalas \\ dessysari55@gmail.com
}

\begin{abstract}
This study aims to examine and analyze the effect of rebranding and perceived quality on consumer loyalty with image as a mediating trademark. The population in this study were all TVRI in the city of Padang. The sampling method used was purposive sampling. Data collection was carried out by means of a questionnaire to 130 respondents. Processing and data analysis was done using SmartPLS. The results showed that rebranding had no significant effect on consumer loyalty, perceived quality had a significant effect on consumer loyalty, brand image had a significant effect on consumer loyalty, rebranding on consumer loyalty through brand image occurred full mediation and perceived quality on loyalty through brand image was partially mediated.
\end{abstract}

Keywords: Rebranding, Perceived Quality, Brand Image, Consumer Loyalty

Abstrak :Penelitian ini bertujuan untuk menguji dan menganalisis pengaruh rebranding dan persepsi kualitas terhadap loyalitas konsumen dengan citra merek sebagai variabel mediasi . Populasinya pada penelitian ini adalah seluruh pemirsa TVRI di Kota Padang. Metode pengambilan sampel yang digunakan adalah purposive sampling. Pengumpulan data penelitian dilakukan dengan menyebarkan kuesioner kepada 130 responden. Pengolahan dan analisis data dilakukan dengan menggunakan SmartPLS. Hasil penelitian menunjukkan bahwa rebranding tidak berpengaruh signifikan terhadap loyalitas konsumen, persepsi kualitas berpengaruh signifikan terhadap loyalitas konsumen, citra merek berpengaruh signifikan terhadap loyalitas konsumen,rebranding terhadap loyalitas konsumen melalui citra merek terjadi mediasi penuh dan persepsi kualitas terhadap loyalitas melalui citra merek terjadi mediasi sebagian .

Kata Kunci:Rebranding, Persepsi Kualitas, Citra Merek, Loyalitas Konsumen

\section{A. PENDAHULUAN}

Televisi menjadi salah satu media yang paling banyak diminati masyarakat dibanding lainnya. Televisi memiliki kelebihan yang sangat efektif (powerful) dalam menyampaikan informasi secara visual kepada masyarakat. Menurut data Badan Pusat Statistik, pada tahun 2016, sebesar 91,47 persen masih menggunakan televisi sebagai akses utama untuk mendapatkan informasi. Besarnya minat masyarakat dalam memperoleh informasi dan hiburan dari televisi dirasakan oleh penduduk hampir di seluruh wilayah Indonesia. Angka partisipasi masyarakat dalam mengakses media massa diduga berkaitan dengan ketersediaan akan fasilitas informasi itu sendiri. Jangkauan sinyal internet yang tidak merata, membuat berita elektronik masih belum bisa mengalahkan eksistensi televisi di masyarakat. Dalam era globalisasi yang terjadi dewasa ini berbagai informasi di seluruh dunia dapat diperoleh melalui berbagai media. Selain sebagai sarana untuk menyampaikan informasi kepada masyarakat, 
media juga berfungsi sebagai sarana menambah pengetahuan dan hiburan. Berdasarkan perkembangannya, media dibedakan menjadi dua jenis. Pertama media tradisional seperti surat kabar, majalah, radio, televisi dan kedua adalah media modern seperti internet dan telepon selular. Bisa dilihat pada Gambar 1.1

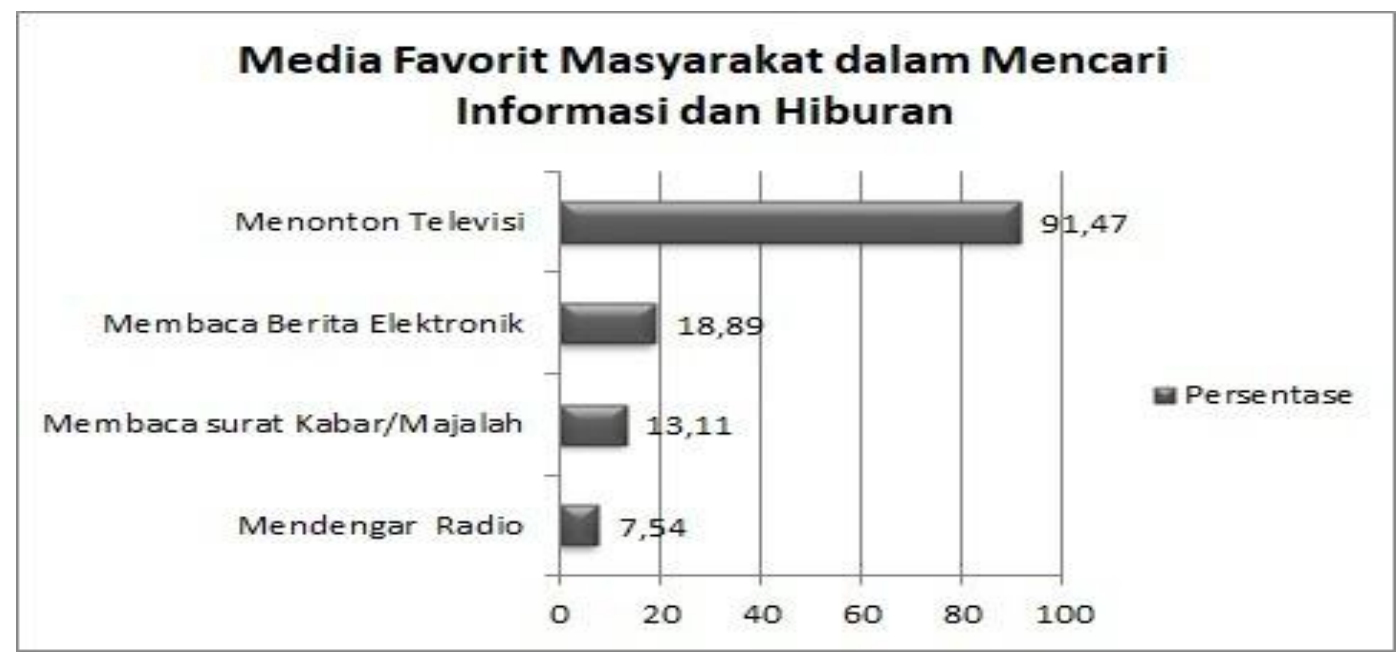

Sumber : Badan Pusat Statistik (BPS), 2016

\section{Gambar 1.1 Televisi Masih Menjadi Media Favorit Masyarakat}

Televisi masih menjadi media utama bagi masyarakat Indonesia. Bisa dilihat pada gambar 1.1 menonton televisi masih menjadi media favorit masyarakat dalam mencari informasi dan hiburan. Hal ini juga tercermin dari survei Nielsen Consumer Media View (CMV) yang menunjukkan bahwa penetrasi televisi mencapai 96 persen. Di urutan kedua media luar ruang dengan penetrasi 53 persen, internet 44 persen, dan di posisi ketiga radio 37 persen. Ini menunjukan bahwasanya televisi masih menjadi market leader di industri media tradisional maupun modern . Bisa dilihat pada gambar 1.2

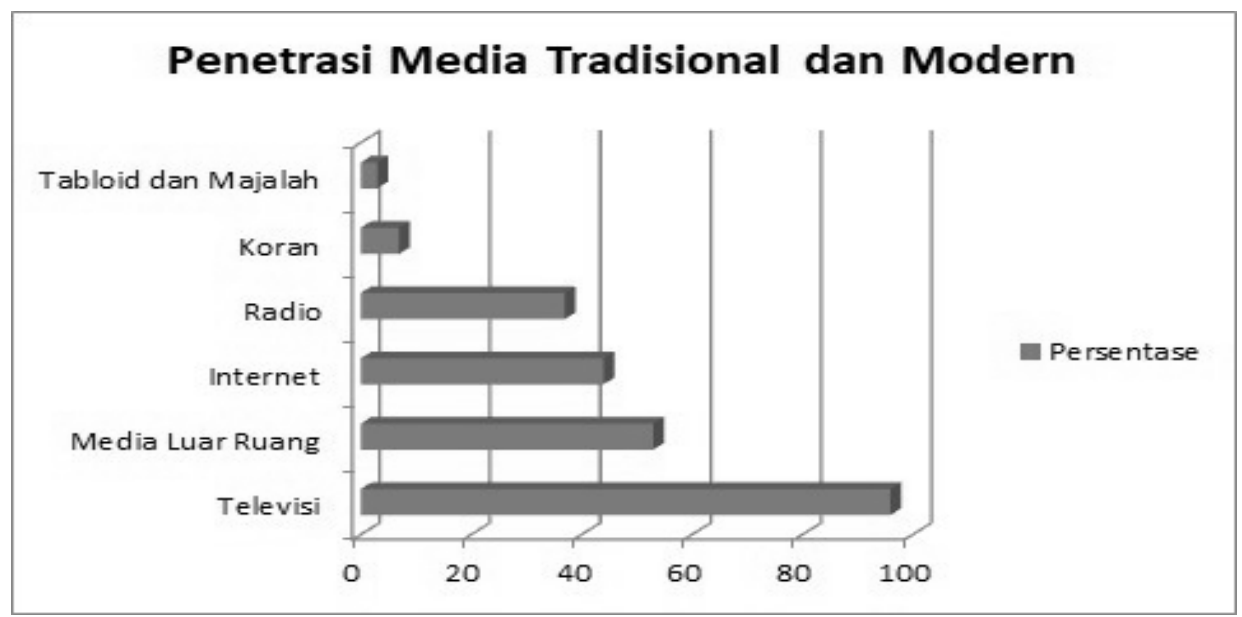

Sumber : Nielsen Indonesia, 2017

Gambar 1.2 Penetrasi Media Televisi Masih Tertinggi 
Televisi Republik Indonesia atau yang dikenal dengan sebutan TVRI merupakan lembaga penyiaran publik milik pemerintah yang mengudara sejak 24 Agustus 1962. Lembaga penyiaran publik menurut UU Nomor 32 Tahun 2002 pasal 14 ayat 1 dan 2 tentang lembaga penyiaran publik mendefinisikan bahwa lembaga penyiaran berbentuk badan hukum yang didirikan oleh negara, bersifat independen, netral, tidak komersial, dan berfungsi memberikan layanan untuk kepentingan masyarakat. Lembaga Penyiaran Publik terdiri atas Radio Republik Indonesia, dan Televisi Republik Indonesia yang stasiun pusat penyiarannya berada di ibukota Negara Republik Indonesia. Sebagai Lembaga Penyiaran Publik milik pemerintah, TVRI memiliki tugas dan fungsi untuk dapat memberikan informasi dan wawasan kepada masyarakat yang dapat mencerdaskan serta mendidik di setiap konten acaranya.

\section{B. KAJIAN TEORI}

\section{Loyalitas Konsumen.}

Menurut Hasan (2014) Loyalitas adalah suatu keadaan psikologis yang berkaitan dengan sikap terhadap produk, konsumen akan membentuk keyakinan, menetapkan suka dan tidak suka, dan memutuskan apakah mereka ingin membeli produk. Menurut Griffin (2005), konsep loyalitas pelanggan lebih banyak dikaitkan dengan perilaku (behavior) dari pada dengan sikap. Bila seseorang merupakan pelanggan loyal, ia menunjukan perilaku pembelian yang didefinisikan sebagai pembelian nonrandom yang diungkapkan dari waktu ke waktu oleh beberapa unit pengambilan keputusan.Dalam bisnis, pelanggan yang setia merupakan suatu aset yang penting bagi perusahaan karena hal ini dapat dipahami dari karakteristiknya, sebagaimana diungkapkan oleh Griffin (2005) bahwa karakteristik pelanggan setia termasuk melakukan pembelian berulang secara teratur, pembelian produk dan layanan inter-line, merujuk ke orang lain dan menunjukkan ketahanan terhadap godaan pesaing. Konsep loyalitas pelanggan tidak banyak dikaitkan dengan sikap akan tetapi lebih banyak dikaitkan dengan perilaku, oleh karena itu, apabila seseorang telah menjadi pelanggan loyal, maka ia akan membuktikannya dengan perilaku pembelian nonrandom yang diungkapkan dari waktu ke waktu oleh beberapa unit pengambilan keputusan (Griffin, 2005).

$\mathrm{H}_{3} \quad$ : Rebranding berpengaruh positif dan signifikan terhadap loyalitas konsumen

$\mathrm{H}_{4}$ :Persepsi kualitas berpengaruh positif dan signifikan terhadap loyalitas konsumen

$\mathrm{H}_{5} \quad$ : Citra merek berpengaruh positif dan signifikan terhadap loyalitas konsumen

\section{Citra Merek.}

Menurut Sangadji dan Sopiah (2013) berpendapat bahwa citra merek merupakan asosiasi yang bersifat positif atau negatif, tergantung pada persepsi seseorang terhadap merek. Watson (2017) menjelaskan Citra dari suatu perusahaan mencerminkan misi organisasi, profesionalisme kepemimpinannya, kaliber para karyawannya dan perannya dalam lingkungan pemasaran atau lanskap politik. Setiap organisasi memiliki citra perusahaan, entah itu mau satu atau tidak. Jika dirancang dan dikelola dengan benar, citra perusahaan akan secara akurat mencerminkan tingkat komitmen organisasi terhadap kualitas, keunggulan dan hubungan dengan berbagai konstituennya termasuk 
pelanggan potensial, karyawan dan staf masa depan, pesaing, mitra, badan pengatur, dan masyarakat umum pada umumnya.

$\mathrm{H}_{1} \quad$ : Rebranding berpengaruh positif dan signifikan terhadap citra merek

$\mathrm{H}_{2} \quad$ :Persepsi kualitas berpengaruh positif dan signifikan terhadap citra merek

\section{Rebranding.}

Muzellec dan Lambkin (2006) mendefinisikan rebranding perusahaan sebagai ciptaan sebuah nama, istilah, simbol, desain, atau kombinasi dari aspek-aspek ini yang baru bagi merek yang telah ditetapkan dengan tujuan untuk mengembangkan posisi baru dan berbeda di benak para pemangku kepentingan, termasuk pelanggan dan pesaing. Rebranding tak sebatas pada perubahan logo saja, namun juga kerapkali melibatkan perubahan nama, gambar, strategi pemasaran, dan tema iklan. Selama ini terdapat banyak pemahaman yang menganggap bahwa rebranding adalah perubahan visual dari identitas dan aplikasi sebuah perusahaan.namun proses rebranding lebih dari perubahan visual.Rebranding merupakan upaya yang dilakukan oleh sebuah perusahaan untuk mengubah secara total atau memperbaharui sebuah brand yang telah ada agar menjadi lebih baik dengan tidak mengabaikan tujuan awal perusahaan, yaitu berorientasi pada profit atau keuntungan. Rebranding dilakukan untuk memperbesar pangsa pasar, tidak hanya di skala lokal, tapi juga global. Perubahan nama dilakukan agar perusahaan dapat menstandarisasikan dirinya secara global (Laily,2018).Citra merek bisa berubah dengan dinamis sewaktu-waktu dan juga bisa berjalan stabil dari waktu ke waktu. Persepsi merupakan salah satu faktor yang dapat melihat citra suatu objek berbeda-beda tergantung dari hal yang berada dalam benak konsumen mengenai objek tersebut, sedangkan opini publik merupakan citra dapat diterima relatif sama pada setiap anggota masyarakat (Watson, 2017).

\section{Persepsi Kualitas.}

Persepsi kualitas (kualitas yang dirasakan) dapat didefinisikan sebagai bentuk pelayanan yang harus disesuaikan dengan harapan dan kepuasan konsumen dalam memenuhi kebutuhan dan keinginan mereka (Wisnu dan Asep, 2011). Persepsi kualitas menyediakan nilai kepada konsumen dengan memberi mereka alasan untuk membeli dan dengan perbedaan merek dengan merek kompetitor. Persepsi kualitas juga digambarkan sebagai evaluasi dan penilaian pelanggan secara menyeluruh mengenai keunggulan dan kualitas penyampaian suatu pelayanan (Santoso, 2003).Persepsi kualitas (perceived quality) merupakan penilaian konsumen terhadap keunggulan atau superioritas produk secara keseluruhan. Oleh sebab itu, persepsi kualitas didasarkan pada evaluasi subjektif konsumen (bukan manajer atau pakar) terhadap kualitas produk. Menurut Setiadi (2010) Persepsi kita dibentuk oleh tiga pasang pengaruh persepsi kualitas (perceived quality) yaitu citra dan reputasi produk serta tanggung jawab perusahaan terhadapnya (Tjiptono, 2008). 


\section{Kerangka Konseptual}

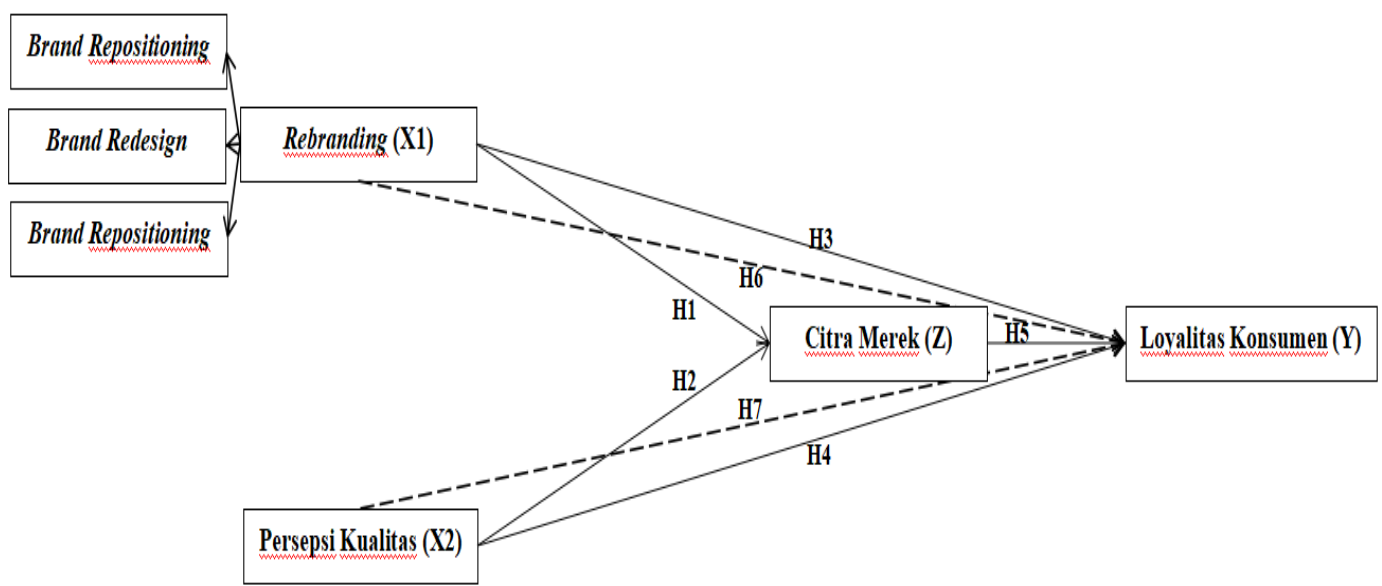

Gambar 1.1 Kerangka Pemikiran

Sumber : Dikembangkan sesuai dengan penelitian, 2020

\section{METODE PENELITIAN}

Populasi dan Sampel. Populasi dalam penelitian yaitu seluruh pemirsa TVRI di Kota Padang. jumlah sampel pada penelitian ini sebanyak 150 responden. Untuk teknik pengambilan sampel pada penelitian ini menggunakan teknik purposive sampling, teknik pengambilan purposive sampling merupakan teknik pengambilan sampel dengan mengajukan beberapa kriteria (Sekaran \& Bougie, 2016). Pada penelitian ini untuk mengukur variabel loyalitas konsumen, citra merek menggunakan indikator yang digunakan oleh (Pratama, 2015),Variabel rebranding menggunakan indikator yang digunakan oleh (Muzellec et al., 2003),(Wiranata dan Yuldinawati, 2014).sedangkan variabel persepsi kualitas menggunakan indikator (Kim et al., 2018 ).

\section{HASIL DAN PEMBAHASAN}

\section{Convergent Validity.}

Uji Validitas atau convergent validity dengan meilhat hubungan atau korelasi antara skor item dengan skor kontruk yang akan menghasilkan nilai loading factor. Suatu item pernyataan atau indikator dinyatakan valid atau berkorelasi tinggi dapat dilihat dari loading factor yang harus lebih beasar dari 0.7, sedangkan untuk penelitian tahap awal dari pengembangan nilai loading factor 0.5 samapai 0.6 dianggap cukup, sebaiknya peneliti tidak menghapus indikator yang memiliki skor loading tersebut, sepanjang skor AVE dan communally indikator tersebut > 0,5 (Ghozali \& Latan, 2012), dari hasil pengujian seluruh item pernyataan dinyatakan handal. Sedangkan jika dilihat dari nilai average variance extracted (AVE) pada setiap variabel lebih besar dari 0,5 dimana setiap variabel telah memenuhi batas minimal yang disyaratkan.

\section{Tabel 1.2 Outer Loading}

\begin{tabular}{cccc}
\hline Item & Outer Loading & Item & Outer Loading \\
\hline CM1 & 0,877 & PK5 & 0,805 \\
CM2 & 0,865 & PK7 & 0,811 \\
CM3 & 0,829 & PK8 & 0,860
\end{tabular}




\begin{tabular}{llll} 
LK1 & 0,911 & RB1 & 0,845 \\
LK2 & 0,898 & RB2 & 0,871 \\
LK3 & 0,857 & RB3 & 0,907 \\
LK5 & 0,826 & RB4 & 0,848 \\
LK6 & 0,729 & RB5 & 0,892 \\
PK1 & 0,855 & RB6 & 0,896 \\
PK2 & 0,816 & RB7 & 0,876 \\
PK3 & 0,795 & RB8 & 0,881 \\
PK4 & 0,854 & RB9 & 0,854 \\
\hline
\end{tabular}

Sumber: Hasil Pengolahan Data Primer, 2020

\section{Discriminant validity.}

Uji validitas discriminant validity akan terjadi apabila pada dua instrument yang digunakan untuk mengukur konstruk tidak berkorelasi menghasilkan skor yang memang tidak berkorelasi. Discriminant validity darimodel pengukuran dengan refleksif indikator dilihat berdasarkan nilai cross loading pengukuran dengan konstruk. Menurut (Ghozali \& Latan, 2012) metode menilai discriminant validity adalah dengan menguji validitas discriminant dengan refleksif yaitu dengan melihat nilai cross loading untuk setiap variabel harus > 0.7. Setelah dilakukan pengujian ditemukan terlihat nilai perbandingan dari nilai akar AVE memperlihatkan bahwa masing-masing dari nilai tersebut lebih besar dibandingkan dengan korelasi antar variabel lainnya. Sehingga dapat disimpulkan bahwa seluruh variabel laten memiliki discriminant validity dan convergent validity yang baik.

\section{Reliability.}

Uji reliabilitas digunakan unutk mengukur suatu konstruk variabel dengan indikator refleksi dengan melihat nilai Composite reliability dan Cronbach' alpha. Suatu kontruk dinyatakan reliabel harus memiliki nilai composite reliability dan cronbach' alpha haruslebih besar dari 0,7 , suatu kontruk yang memiliki nilai composite reliability dan cronbach' alpha lebih besar dari 0,7 maka suatu konstruk dinyatakan reliabel, nilai apabila composite reliability dan cronbach' alpha 0.6 masih dapat diterima (Ghozali \& Latan, 2012). Setelah dilakukan pengujian ditemukan bahwa seluruh variabel memiliki nilai composite reliability dan cronbach' alpha lebih besar dari 0,7, maka seluruh variabel dinyatakan handal.

\section{R-Square (R2).}

Nilai R- Square menggambarkan bahwa variabel loyalitas konsumen dapat dijelaskan oleh citra merek, rebrandingdan persepsi kualitas sebesar 0,744 atau (74,4\%), sedangkan selebihnya $(25,6 \%)$ dipengaruhi oleh variabel lain yang tidak ada dalam penelitian ini. Citra merek dapat dijelaskan oleh rebranding dan persepsi kualitas sebesar 0,613 atau $(61,3 \%)$, sedangkan selebihnya $(38,7 \%)$ dipengaruhi oleh variabel lain yang tidak dijelaskan pada penelitian ini.

\section{Uji Hipotesis.}

Untuk melihat signifikansi pengaruh rebranding, persepsi kualitas dan citra merek terhadap loyalitas konsumen adalah dengan melihat nilai koefisien parameter dan nilai signifikansi $t$-statistic dan $P$-value. Tingkat signifikansi dalam pengujian hipotesis 
ditujukan oleh nilai koefisien pathatau inner model. Hasil dari dari koefisien path atau inner model dapat dilihat pada Tabel 4.11 berikut ini:

Tabel 1.3 Path Coefficients

\begin{tabular}{lccccc}
\hline \multicolumn{1}{c}{ Hubungan } & $\begin{array}{c}\text { Original } \\
\text { Sample }\end{array}$ & $\begin{array}{c}\text { Sample } \\
\text { Mean }\end{array}$ & $\begin{array}{c}\text { Standard } \\
\text { Deviation }\end{array}$ & T Statistics & P Values \\
\hline RB -> CM & 0.225 & 0.228 & 0.090 & 2.510 & 0.012 \\
RB -> LK & 0.014 & 0.013 & 0.078 & 0.185 & 0.853 \\
CM -> LK & 0.666 & 0.662 & 0.088 & 7.556 & 0.000 \\
PK -> CM & 0.620 & 0.618 & 0.082 & 7.520 & 0.000 \\
PK -> LK & 0.231 & 0.239 & 0.095 & 2.441 & 0.015 \\
& & & & & \\
RB -> CM -> LK & 0,150 & 0,153 & 0,064 & 2,419 & 0,016 \\
PK -> CM-> LK & 0,413 & 0,413 & 0,083 & 4,917 & 0,000 \\
\hline
\end{tabular}

Sumber: Hasil Pengolahan Data Primer, 2020

Hasil pengujian koefisien pathatau inner model pada penelitian ini dapat dilihat pada Tabel 1.3, dengan hasil dan keterangan sesuai dengan hipotesis yang diajukan sebagai berikut:

Rebranding memiliki nilai koefisien 0,225, sedangkan jika dilihat dari nilai T-statistik sebesar 2,510 dan nilai p-values sebesar 0,012, dimana nilai koefisien yang diperoleh berslot positif, sedangakan nilai T-statistik lebih besar dari 1,98 dan nilai p-value yang lebih kecil dari 0,05, artinya rebranding berpengaruh positif dan signifikan terhadap citra merek, maka $\mathrm{H}_{1}$ pada penelitian ini diterima.

Persepsi kualitas memiliki nilai koefisien 0,620, sedangkan jika dilihat dari nilai T-statistik sebesar 7,520 dan nilai p-values sebesar 0,000, dimana nilai koefisien yang diperoleh berslot positif, sedangakan nilai T-statistik lebih besar dari 1,98 dan nilai p-value yang lebih kecil dari 0,05, artinya persepsi kualitas berpengaruh positif dan signifikan terhadap citra merek, maka $\mathrm{H}_{2}$ pada penelitian ini diterima.

Rebranding memiliki nilai koefisien 0,014, sedangkan jika dilihat dari nilai T-statistik sebesar 0,185 dan nilai p-values sebesar 0,853 , dimana nilai koefisien yang diperoleh berslot positif, sedangakan nilai $\mathrm{T}$-statistik lebih kecil dari 1,98 dan nilai p-value yang lebih besar dari 0,05, artinya rebranding berpengaruh positif dan tidak signifikan terhadap loyalitas Konsumen, maka $\mathrm{H}_{3}$ pada penelitian ini ditolak.

Persepsi kualitas memiliki nilai koefisien 0.231, sedangkan jika dilihat dari nilai T-statistik sebesar 2.441 dan nilai p-values sebesar 0.015, dimana nilai koefisien yang diperoleh berslot positif, sedangakan nilai T-statistik lebih besar dari 1,98 dan nilai p-value yang lebih kecil dari 0,05, artinya persepsi kualitas berpengaruh positif dan signifikan terhadap loyalitas konsumen, maka $\mathrm{H}_{4}$ pada penelitian ini diterima.

Citra merek memiliki nilai koefisien 0,666, sedangkan jika dilihat dari nilai T-statistik sebesar 7,556 dan nilai p-values sebesar 0,000, dimana nilai koefisien yang diperoleh berslot positif, sedangakan nilai T-statistik lebih besar dari 1,98 dan nilai p-value yang lebih kecil dari 0,05, artinya citra merek berpengaruh positif dan 
signifikan terhadap loyalitas konsumen, maka $\mathrm{H}_{5}$ pada penelitian ini diterima.

\section{Uji Pengaruh Mediasi.}

Efek mediasi menunjukan hubungan antara variabel independen dan dependen melalui variabel penghubung atau mediasi. Metode yang digunakan yaitu variance accounted for (VAF) yang dikembangkan oleh Preacher dan Hayes serta bootstrapping dalam distriibusi pengaruh tidak langsung dipandang lebih sesuai karena tidak memerlukan asumsi apapun tentang distribusi variabel sehingga dapat diaplikasikan pada ukuran sampel kecil. Jika nilai VAF di atas $80 \%$, maka menunjukkan peran variabel mediasi sebagai pemediasi penuh (mediasi penuh). Dapat dikategorikan sebagai pemediasi parsial apabila nilai VAF meningkat antara $20 \%$ sampai dengan $80 \%$, namun jika nilai VAF kurang dari $20 \%$ dapat disimpulkan bahwa tidak ada efek mediasi. Hasil dari perhitungan efek mediasi dengan menggunakan metode variance accounted for (VAF) sebagai berikut:

1. Perhitungan nilai VAF untuk melihat peranan citra merek sebagai variabel mediasi antara rebranding dan loyalitas konsumen sebagai berikut:

$$
\left.\mathrm{VAF}=\frac{0,150}{(0,014+0,150)} \quad \mathrm{VAF}=0,9146 \text { atau } 91,46 \% \text { (Fullmediasi }\right)
$$

2. Perhitungan nilai VAF untuk melihat peranan citra merek sebagai variabel mediasi antara persepsi kualitas dan loyalitas konsumen sebagai berikut:

$$
\mathrm{VAF}=\frac{0,413}{(0,231+0,413)} \quad \mathrm{VAF}=0,6304 \text { atau } 63,04 \%(\text { Partial mediasi })
$$

\section{E. HASIL PENELITIAN DAN PEMBAHASAN}

\section{Pengaruh Rebranding Terhadap Citra Merek.}

Rebranding berpengaruh positif dan signifikan terhadap citra merek. Hasil penelitian yang ditemukan sejalan dengan penelitian yang terdahulu, Caniago et al. (2014) menyatakan bahwasanya efek dari rebranding suatu produk atau jasa dapat mempengaruhi citra merek menunjukkan bahwa rebranding perusahaan memiliki pengaruh signifikan terhadap citra merek. Hasil penelitian ini mendukung penelitian oleh Bamiduro dan Aremu (2012) yang menegaskan pengaruh rebranding perusahaan terhadap citra merek.Muzellec dan Lambkin (2006) mengemukakan bahwa proses rebranding adalah suatu proses menciptakan gambaran baru dan posisi baru di pikiran konsumen dari suatu brand yang sudah ada, untuk membangun positioning yang berbeda di mata konsumen dan kompetitor.

Pengaruh yang positif membuktikan bahwa rebranding memberikan dampak yang positif terhadap citra merek artinya semakin efektif dan tepat rebranding dilakukan akan memberikan dampak meningkatnya citra merek perusahaan dimata pemirsa, dimana rebranding berpengaruh signifikan terhadap citra merek disebabkan karena semua responden penelitian sudah pernah menonton TVRI sebelum dan sesudah rebranding,maka responden melihat terjadi perubahan akibat rebranding yang mana sebelum rebranding citra ketinggalan zaman yang melekat pada TVRI yang mengakibatkan sebagus apapun program acara yang dimasukan ke TVRI maka tidak akan ditonton oleh pemirsa,setelah dilakukang rebranding TVRI mengusung tema televisi kekinian agar menciptakan citra baru sehingga membuat citra merek lebih baik setelah rebranding. 


\section{Pengaruh Persepsi Kualitas Terhadap Citra Merek.}

Persepsi Kualitas berpengaruh positif dan signifikan terhadap citra merek. Hasil penelitian yang ditemukan sejalan dengan penelitian yang terdahulu,Alhaddad (2015) menemukan bahwasanya persepsi kualitas berpengaruh positif dan signifikan terhadap citra merek . Selaras dengan itu Ming et al (2011) hasil penelitian ini membuktikan bahwasannya persepsi kualitas berpengaruh positif dan signifikan terhadap citra merek.Pengaruh yang positif membuktikan bahwa persepsi kualitas memberikan dampak yang positif terhadap citra merek artinya semakin baik kualitas yang diberikan oleh TVRI akan memberikan dampak meningkatnya citra merek perusahaan.Pada sebuah televisi misalnya, aspek produk adalah ukuran layar, gambar, suara, kelengkapan fungsi, dan desain. Sementara itu, aspek non-produk terdiri dari garansi, reputasi, dan layanan perbaikan.dengan meningkatkan aspek produk dan non-produk pada TVRI maka akan meningkatkan citra merek TVRI.

\section{Pengaruh Rebranding Terhadap Loyalitas Konsumen.}

Rebranding berpengaruh positif dan tidak signifikan terhadap loyalitas konsumen.Tevi (2013) mengungkapkan bahwa rebranding tidak berpengaruh signifikan terhadap sikap pelanggan dalam memilih merek, sehingga meyebabkan pelanggan tidak loyal. Rebranding tidak berpengaruh signifikan terhadap loyalitas konsumen terjadi karena tidak ada perbedaan yang jelas antara merek lama dan merek baru (Ha et al,2011 ).Hasil penelitian ini tidak selaras dengan penelitian terdahulu Nyambane dan Ezekiel (2013) dalam penelitiannya menemukan bahwasanya rebranding perusahaan memiliki efek positif dan signifikan terhadap loyalitas pelanggan. Anggoro (2013) menunjukkan ada hubungan positif dan signifikan antara rebranding terhadap loyalitas konsumen.Hasil dari penelitian ini selaras dengan penelitian Penelitian Bamfo et al. (2017) rebranding berpengaruh positif dan tidak signifikan terhadap loyalitas konsumen. Jadi hal ini menunjukan bahwa rebranding berpengaruh positif yang berarti memiliki pengaruh terhadap loyalitas konsumen tetapi tidak signifikan . juga selaras dengan Olafsson (2010) menemukan rebranding bank-bank Islandia memiliki pengaruh yang sangat kecil pada loyalitas pelanggan di akibatkan publik telah kehilangan banyak kepercayaan pada bank-bank ini sehingga, kegiatan rebranding tidak dapat menyelamatkan citra perusahaan yang berakibat pada hilangnya loyalitas konsumen.Tevi (2013) juga tidak menemukan pengaruh yang signifikan secara statistik dari multiple rebranding pada loyalitas pelanggan Nigerian Mobile Telephony.

\section{Pengaruh Persepsi Kualitas Terhadap Loyalitas Konsumen.}

Persepsi kualitas berpengaruh positif dan signifikan terhadap loyalitas konsumen. Penelitian ini selaras dengan penelitian terdahulu Tuan dan Rajagopal (2017) menemukan bahwa persepsi kualitas berpengaruh positif dan signifikan terhadap loyalitas konsumen.selaras dengan itu Ihsan dan Herlina (2015) membuktikan bahwasanya Persepsi Kualitas berpengaruh positif dan signifikan terhadap loyalitas konsumen.Pengaruh yang positif membuktikan bahwa persepsi kualitas memberikan dampak yang positif terhadap loyalitas konsumen artinya semakin baik kualitas yang diberikan oleh TVRI akan memberikan dampak terhadap loyalitas konsumen.Pada sebuah televisi misalnya, aspek produk adalah ukuran layar, gambar, suara, kelengkapan fungsi, dan desain. Sementara itu, aspek non-produk terdiri dari garansi, reputasi, dan layanan perbaikan.dengan meningkatkan aspek produk dan non-produk pada TVRI maka akan meningkatkan loyalitas pemirsa TVRI. 


\section{Pengaruh Citra Merek Terhadap Loyalitas Konsumen.}

Citra berpengaruh positif dan signifikan terhadap loyalitas konsumen. Penelitian ini selaras dengan penelitian terdahulu Ogba dan Tan (2014) dalam penelitiannya menemukan brand image berpengaruh positif dan signifikan terhadap loyalitas konsumen. Gadau (2014) juga menemukan bahawsanya brand image berpengaruh positif dan signifikan terhadap loyalitas konsumen.Pengaruh yang positif membuktikan bahwa citra merek memberikan dampak terhadap loyalitas konsumen, semakin baik citra merek akan memberikan dampak meningkatnya loyalitas konsumen.Schiffman dan Kanuk (2008) menyebutkan citra merek yang positif memiliki kaitan erat dengan kesetian (loyalitas konsumen) dalam membeli produk, memiliki kepercayaan dan memikirkan nilai positif dan mencari merek tersebut.

\section{Citra Merek Memediasi Rebranding dan Loyalitas Konsumen.}

Berdasarkan hasil uji hipotesis menyebutkan bahwa citra merek dapat memediasi secara penuh atau full mediating karena nilai VAF (variance accounted for) yaitu $91,46 \%$. Oleh karena itu nilai VAF lebih besar dari $80 \%$ yang berarti citra merek memiliki pengaruh mediasi penuh atau full mediating (Hair et al , 2010). Winata dan Andjarwati (2019) hasil penelitian menunjukkan bahwa rebranding berpengaruh signifikan terhadap citra merek, dan citra merek memiliki pengaruh signifikan terhadap loyalitas. Hasil penelitian ini menunjukkan bahwa rebranding tidak secara langsung mempengaruhi loyalitas dan melalui citra merek sebagai variabel mediasi. Dalam tes mediasi ini, rebranding dan loyalitas terbukti sepenuhnya dimediasi oleh citra merek.penelitian itu juga didukung oleh Sulibhavi dan Shivashankar (2017) menunjukkan bahwa ada hubungan yang positif dan signifikan antara citra merek langsung dan loyalitas pelanggan.Hal ini menunjukan bahwa citra merek yang memediasi penuh antara rebranding dan loyalitas konsumen.Artinya sebesar apapun perubahan rebranding dilakukan oleh TVRI maka tidak akan memberikan dampak yang begitu besar secara langsung pada loyalitas pemirsa TVRI, namun rebranding dapat memberikan dampak tidak langsung terhadap loyalitas konsumen ketika dimediasi oleh citra merek, dimana rebranding dapat meningkatkan citra merek pada pemirsa, dengan semakin tingginya citra merek TVRI dimata pemirsa maka akan menciptakan loyalitas konsumen yang tinggi pula.

\section{Citra Merek Memediasi Persepsi Kualitas dan Loyalitas Konsumen.}

Berdasarkan hasil uji hipotesis menyebutkan bahwa citra merek dapat memediasi secara parsial karena nilai VAF (variance accounted for) yaitu 63,04\% .Citra merek dikategorikan sebagai pemediasi parsial karena nilai VAF berkisar antara $20 \%$ sampai dengan $80 \%$.Alhaddad (2015) hasil penelitian ini menunjukan bahwasannya persepsi kualitas berpengaruh positif dan signifikan terhadap citra merek. Selaras dengan itu Ming et al.(2011) hasil penelitian ini membuktikan bahwasannya persepsi kualitas berpengaruh positif dan signifikan terhadap citra merek.Ogba dan Tan (2014) dalam penelitiannya menemukan Brand Image berpengaruh positif dan signifikan terhadap loyalitas konsumen. Gadau (2014) juga menemukan bahawsanya brand image berpengaruh positif dan signifikan terhadap loyalitas konsumen.Schiffman dan Kanuk (2008) menyebutkan citra merek yang positif memiliki kaitan erat dengan kesetian dalam membeli produk, memilki kepercayaan dan memikirkan nilai positif dan mencari merek tersebut.Hal ini menunjukan bahwa citra merek yang memediasi sebagian antara rebranding dan loyalitas konsumen.Artinya jika terjadi perubahan 
terhadap kualitas oleh TVRI maka akan memberikan dampak yang secara langsung pada loyalitas pemirsa TVRI tidak harus melalui variabel mediasi atau dalam penelitian ini variabel citra merek, namun persepsi kualitas dapat memberikan dampak tidak langsung terhadap loyalitas konsumen ketika dimediasi oleh citra merek, dimana persepsi kualitas dapat meningkatkan citra merek pada pemirsa, dengan semakin tingginya citra merek TVRI dimata pemirsa maka akan menciptakan loyalitas konsumen yang tinggi pula.

\section{F. PENUTUP}

\section{Kesimpulan.}

Berdasarkan hasil analisis dan pembahasan pada bab sebelumnya maka dapat diambil kesimpulan, Rebranding berpengaruh signifikan terhadap loyalitas konsumen TVRI di Kota Padang, Persepsi Kualitas berpengaruh signifikan terhadap loyalitas konsumen TVRI di Kota Padang, Rebranding berpengaruh positif dan tidak signifikan terhadap loyalitas konsumen,Persepsi Kualitas berpengaruh positif dan signifikan terhadap loyalitas konsumen,Citra merek berpengaruh positif dan signifikan terhadap loyalitas konsumen,Citra merek berperan sebagai variabel mediasi penuh antara rebranding dan loyalitas konsumen, dan Citra merek berperan sebagai variabel mediasi sebagian antara persepsi kualitas dan loyalitas konsumen.

\section{G. DAFTAR RUJUKAN}

Alhaddad, A.(2015).Perceived Quality, Brand Image and Brand Trust asDeterminants of Brand Loyalty.Journal of Research in Business and Management.3 (4),1-8

Anggoro, A.B. (2013). Pengaruh Perubahan Merek (Rebranding) Produk Larutan Penyegar Cap Kaki Tiga Menjadi Cap Badak Terhadap Loyalitas Konsumen. jurnal Ekonomi dan Bisnis.10, 19-29.

Bamfo, B.A., Dogbe, C.S.K., \& Wusu, C.O. (2017). The effects of corporate rebranding on customer satisfaction and loyalty Empirical evidence from the Ghanaian banking industry. Cogent Business \&Management,4 (1413970),1-11. https://doi.org/10.1080/23311975.2017.1413970

Bamiduro, J.A, \&Aremu M.A. (2012). Assessment of the Need for and Effectiveness of Re-Branding in Nigeria.International Journal of Management and Administrative Sciences (IJMAS), 12, 12-26.

Caniago, A., Suharyono., Arifin, Z., \& Kumadji, S. (2014).The Effects of Service Quality and Corporate Rebranding on Brand Image, Customer Satisfaction, Brand Equity and Customer Loyalty (Study in Advertising Company at tvOne). European Journal of Business and Management , 6 (19), 118-126.

Gadau, M. (2009).pengaruh citra merek terhadap loyalitas konsumen.(Skripsi, Univeristas Sanata Dharma,2009). Diakses dari https://repository.usd.ac.id/6581/2/122214107_full.pdf.

Ghozali, I., \& Latan, H. (2012). Partial Least Square. Konsep, Teknik dan Aplikasi SmartPLS 2.0. Badan Penerbit Universitas Diponegoro. 
Griffin, J. (2005). Customer Loyalty : Menumbuhkan \& Mempertahankan Kesetiaan pelanggan. Jakarta : Erlangga.

Ha, HY, John, J., Janda, S., \& Muthaly, S. (2011 ). Efek dari pengeluaran iklan untuk loyalitas merek dalam layanan.European Journal of Marketing, 45 (4), 673-691.https://doi.org/10.1108/03090561111111389

Hair, J., Black, W., Babin, B., \& Anderson, R. (2010). Multivariate Data Analysis. 7th Edition. New Jersey: Pearson Prentice Hall.

Hasan, A. (2014). Marketing dan Kasus-kasus Pilihan (2nd ed.).Yogyakarta : CAPS(Center for Academic Publishing Service).

Ihsan, R.A. \& Herlina.(2015).Analisis Pengaruh Persepsi Kualitas dan Persepsi Nilai Terhadap Loyalitas Konsumen Pengguna Sarana Lapangan Olahraga Futsal Di Bandar Lampung. Jurnal Bisnis Darmajaya,01 (02),1-16.

Kim, S., Chou, J.Y., \& Patrich J.F.(2018).The effect of celebrity on brand awareness, perceived quality, brand image,brand loyalty, and destination attachment to a literary festival.Journal of Destination Marketing \& Management, 2-10.

Laily M.Z.(2018). Corporate Rebranding Tokobagus.com menjadi OLX.co.id. Jurnal Ilmiah Teknik dan Manajemen Industri,1(1), 2620-5793.

Ming, T.T, Ismail,H.B, \& Rasiah, D.(2011).Hierarchical Chain Of Consumer-Based Brand Equity: Review From The Fast Food Industry.International Journal of Economics and Business Research,10 (9), 67-80.

Muzellec, L., \& Lambkin, M. (2006). Corporate rebranding: destroying, transferring or creating brand equity?. European Journal of Marketing. 40 (7/8), 803-824.

Nyambane, M.M \& Ezekiel, M.M. (2013). The relationship between rebranding and customer loyalty: The case of Kenya Power. International Journal of Science and Research (IJSR), 4 (3), 995-1001.

Ogba, I.E., \& Tan, Z.(2014).Exploring the impact of brand image on customer loyalty and commitment in China. Journal of Technology Management in China. 4(2), 132-144. DOI: 10.1108/17468770910964993.

Pratama, I.M. (2015). Pengaruh rebranding terhadap citra bank jambi pada nasabah. Jurnal Kajian Komunikasi, 3, 140-147.

Sangadji, E.M., \& Sopiah. (2013). Perilaku Konsumen: Pendekatan Praktis Disertai Himpunan Jurnal Penelitian. Yogyakarta: Penerbit Andi.

Santoso, J. (2003). E-service quality: Amodel of virtual service qualitydimension, Journal Managing Service Quality, 13 (3) 233-246.

Schiffman \& Kanuk. (2008). Perilaku konsumen(7th ed.). Jakarta: Indeks.

Sekaran, Uma \& Bougie, R. (2016). Research Methods for Business. John Wiley \& Ons Ltd. 
Setiadi, N. J. (2010). Perilaku Konsumen (Ed 4). Jakarta: Kencana

Sulibhavi, B., \& Shivashankar K. (2017).The Impact of Brand Image on Customer's Loyalty Towards Private Label Brands: The Mediating Effect of Satisfaction. International Journal of Marketing \& Financial Management, 5 (8), 43-50.

Tevi, A.C. (2013). The Effect of Multiple Rebranding on Customer Loyalty in Nigerian Mobile Telephony, School of Media and Communication, Pan African University, Lagos, , Online Published: March 5, 2013. Nigeria.

Tjiptono, F., \& Chandra, G.(2012). Pemasaran Strategik. Yogyakarta : Andi Offset.

Tuan, V.K. \& Rajagopal, P.(2017).The Mediating Effect Of Perceived Quality on The Customer Loyalty in Small And Medium-Sized Enterprises (SMEs) in The Mobile Phone Sector in Ho Chi Minh City (HCMC)- Vietnam.International Journal of New Technology and Research (IJNTR),3 (11),129-137.

Watson, B. (2017).The effect of rebranding on customer loyalty with it's image as an intervening variabel study in Bank Nagari main padang branch.(thesis magister, Universitas andalas, 2017). Diakses dari http://scholar.unand.ac.id/.

Winata, D.H., \& Andjarwati, A.L. (2019).Pengaruh rebranding terhadap loyalitas dengan citra merek sebagai variabel mediasi (studi pada PO Sugeng Rahayu).Jurnal Ilmu Manajemen, 7 (2), 327-333.

Wiranata, A. \& Yuldinawati, L. (2014).Pengaruh rebranding terhadap citra Bank Jambi pada nasabah (Studi Pengaruh Perubahan Nama, Logo, Slogan dan Frontliner Terhadap Citra Bank Jambi pada Nasabah Kantor Cabang Utama). Jurnal Manajemen Bisnis Telekomunikasi dan Informatika, 4 (2), 21-30.

Wisnu \& Hermawan A,.(2011).Pengaruh Perceived Quality Terhadap Kesetian Merek dan Citra Merek. Jurnal manajemen dan pemasaaran jasa, 4,39-50. 